\title{
Kaleidoskop historické sociologie
}

Někdy mne napadá kacířská myšlenka, že by bylo možné obejít se bez původních oborů, které jsem vystudoval. Ale nakonec i těch, v nichž jsem až dosud s různou měrou intenzity účinkoval. Ovšem tak daleko jako Michel Foucault se v nejbližší době rozhodně nedostanu. Když totiž 2. prosince 1970 nastupoval na Collège de France, měl za úkol pronést povinnou nástupní řeč. Jako téma svého právě zahajovaného působení na katedře uvedl Dějiny systémů myšlení, čímž chtěl shrnout své předchozí bádání od Dějin šilenství po Archeologii vědění. Do hry se dále měly dostat také ,jevy obecného mínění', nehledě na „schopnost dívat se dovnitř nebo do hloubky“. Mimochodem, Dějiny šílenství se v kontextu svého hlavního tématu a pod jeho zorným úhlem zaměřovaly na vznik a přeměny vztahů, strategií, mechanismů a institucí, pomocí nichž se západní kultura jako sféra rozumu profiluje proti ne-rozumu.

Vždycky, když mi do cesty vstoupí nějaké otázky, hledám uklidňující zákoutí či niky, které mi odkrývají netušené obrazy. Vytvářejí jakýsi kaleidoskop či dětskou skládačku. Tuto optickou hračku vytvořil Francouz Alfonse Giroux a patentovat si ji nechal už roku 1818. Kaleidoskop připomínající malý dalekohled nazval „transfigurátor“, nebo se mu také říkalo „francouzské brýle“. Pomalým otáčením vznikají pravidelné vizuální kreace; z roztroušených zlomků se rýsují fascinující výtvory a pestrobarevné obrazy.

Právě na vizuální materiál kaleidoskopu nápaditě naráží francouzský filozof a teoretik umění Georges Didi-Huberman [2006: 112-119], jenž v této souvislosti dále akcentuje „bludnou montáź" a demontáž struktury věcí vůbec. Přitom nemusí jít pouze o výtvarné umění, tedy o esteticky působící tvary, malbu nebo fotografii, nýbrž i další doklady minulosti. Didi-Huberman v narážce na Marca Blocha píše, že historie není v pravém slova smyslu věda o minulosti, nebot minulost existuje jen skrze své „přecezení'. Odkazuje při této př́ležitosti rovněž na Waltera Benjamina a jeho pojetí „materiální archeologie“. Podle něj existují materiální stopy, poté zbytky a nakonec odpady dějin, přičemž v potaz se bere i miniaturní svět.

Excelentně by se jistě o shora naznačených otázkách vyjádřila filozofka a vizuální teoretička Michaela Fišerová, která v této debatě podotýká, že fotografie je pokládána za jeden z nejvěrohodnějších obrazů, na které se historikové odvolávají. Nabízí pak př́ílad historika Jacquese Le Goffa, který byl toho názoru, že kdyby fotografie existovala již dříve, obohatilo by se tím poznání středověku. Nejen to - dodávám ve smyslu Clauda Lévi-Strausse, že třeba jen pětiminutový film by jistě výrazně pozměnil poznání starověkých Athén.

V tomto duchu vedla Michaela Fišerová [2015] diskuzi s francouzskými badateli, hlavně teoretiky obrazu, načež poukázala na sdílení viditelného jako politiku vizualizace neviditelného. Samotný výše zmíněný Georges Didi-Huberman se stal „objektem“ jejího rozhovoru. Rád bych vyslovil přání, zda bych pro změnu zase já nemohl prostřednictvím 
časopisu Historická sociologie rozmlouvat s Michaelou Fišerovou o jejich dalších setkáních, objevech apod.

Určitě by bylo možné publikovat na stránkách Historické sociologie díla dalších badatelek a badatelů, které a kteří se pohybují ve stejně zajímavých badatelských oblastech. Patří mezi ně tř̌ebas Helena Bendová [2016], která nejednou výstižně pojednala o počítačových hrách. Dnešního čtenáře, at už odborníka či laika, určitě zaujmou otázky umění počítačových her, sociální a institucionální kontext digitální hravosti, specifika herního vyprávění (respektive obecná problematika ludologie a naratologie), designerské i hráčské improvizace apod. Doplňme ještě, že kolegyně Bendová působí v Centru audiovizuálních studií na FAMU, věnuje se hlavně dějinám a teorii filmu. Pozoruhodný výsledek její práce představuje sborník Společenské vědy a audiovize [2014], jejž sestavila spolu s Matějem Strnadem.

Na pomezí řady oborů dnes vzniká komplexní studium širší modifikace textů, kde se odrážejí různé podoby textuality. Do takto koncipované, otevřené hry vstupuje sama literatura v podobě četných svých druhových a žánrových variant, především jako literatura populární, pokleslá, masová a lidová, včetně folkloru. Zcela jistě by se k tomuto historickému „polohováni“ textů mohla vyslovit Sylva Fišerová [2012; 2016]. Ve středu jejího zájmu je totiž klasická řecká literatura, náboženství a filozofie, stejně tak úžeji antický román, chápaný právě jako zárodek populární literatury.

Od dob Norberta Eliase je zřejmé, že historická sociologie představuje výzkumnou orientaci, která se nezaměřuje jen na „velké dějiny“, ale nachází svůj předmět i v oblastech spojených s mikro- a mezoúrovní sociální reality. Předmětem jejího odborného zájmu se stávají nejen politické události, ekonomické trendy, konflikty nebo krize, ale také proměny každodennosti. Tudy ostatně vede i má vlastní současná cesta, ke které patří téma motorizace. Dějiny automobilismu a turismu mají v „ostrém merku“ Ivan Jakubec [například 2018] a Jan Štemberk. Vysokou poznávací úroveň má rovněž jejich společná monografie o cestovním ruchu v protektorátu Čechy a Morava (1939-1945) [Jakubec - Šternberk: 2018] Na základě rozsáhlých archivních pramenů se tu věnují domácímu a zahraničnímu cestovnímu ruchu, ubytovacím a stravovacím službám, dopravě a dalším předpokladům.

Nelze než vrátit se s badatelskou pokorou „zpátky na zem“, zvláště když obrovský rozsah současného vědění se dále násobí. A to se nebavíme o tom, zda třeba i kvalitní výzkum vưbec přiláká odpovídající pozornost. Proniknout skrze mlhu všeobecné zahlcenosti by mohl například způsob života středověkých monastických korporací. Nejen oborové čtenáře by dnes dokázalo upoutat téma ticha, které představovalo integrální součást vnitřního života řeholních komunit. S odvoláním na výše zmíněného Foucaulta se dá konstatovat, že všechno má své dějiny, což se týká i podob mlčení (jeho genealogie) v mnišské tradici. Na tomto poli dosáhla onoho nesnadného úspěchu Radka Těšínská Lomičková se svou knihou vydanou v nakladatelství Karolinum. Jakkoliv se na první pohled může zdát, že jde o pouhý dílčí úkol, závažnost tématu se tím nijak nesnižuje.

V přehledu kýžené časopisecké účasti pozoruhodných soudobých výzkumníků neopomeňme folkloristiku v podání Petra Janečka [např́íklad 2017] a Jana Pohunka [2015]. Oba badatelé se pohybují (byt každý trochu jinak) v oblasti studia moderních legend. Zároveň ovšem pozor, folkloristika není věda o čistém myšlení, o věcech racionálních, nýbrž o ryzím iracionálnu, tedy o pověrách. Folkloristiku lze tudíž nejlépe chápat jako vědu o vymyšleném - co si lidé všechno vymysleli pro zábavu a poučení. Dnes už nikoho jen trochu zvídavějšího nepřekvapí, že lidská mysl může být (a v časech sociálních sítí typu 
Insta Stories skutečně je) strukturována narací. V tomto směru není třeba se obávat myšlenky, že narativy jsou cosi primárního, neredukovatelného, svým způsobem primitivního. Folkloristika se také na pozadí př́běhových struktur zabývá studiem rozmanitých textuálních elementů, proč bychom se tedy měli bát tematologie? Právě takovéto textuální elementy fungují jako „story“, jinak řečeno zakládají pojetí akce, souvisejících stavů mysli, cítění a gest. Nepřekvapí tudíž, že existuje tisíce potencialit motivů a k dispozici jsou národní a mezinárodní katalogy prozaického folkloru.

V naznačených souvislostech nelze zapomenout na Jana Luffera [2014], který výrazně přispěl k poznání českých i evropských tradičních pověstí, přičemž sestavil také příslušný katalog. České pohádky zase nápaditě vřadil do mezinárodních souvislostí Jaroslav Otčenášek [2012; 2019]. A výše jmenovaný Petr Janeček je autorem rozsáhlé knihy Mýtus o Pérákovi. Mèstská legenda mezi folklorem a populární literaturou [2017], kde tuto fiktivní postavu probírá v širokém českém a evropském kontextu.

Dnes ovšem povětšinou běží o zcela odlišné polohování textů, což se dotýká i mého zájmu o historickou sociologii textů, k níž se úzce přimyká etnografie čtení. V jejím rámci zkoumáme konkrétní čtenářské praktiky a taktiky, takže ve výsledku vše vyhlíží trochu jako pověstná brikoláž - kombinace nejrůznějších přístupů, ne nepodobná modifikačním hrátkám s kaleidoskopem.

Hlavní je dokázat si poradit, aby věci fungovaly, at’ už na materiálním a praktickém, nebo mentálním a teoretickém poli. Opravit, upravit, zadrátovat, heftnout, to nejspíš můj předek František Šalanda (1882-1919) velmi dobře uměl. Nedokázal se ale přesto dostat ze zajateckého lágru v ruské Střední Asii, ve Skobelevu, kde v únoru 1919 zemřel na nákazu. Abych byl spravedlivý, můj otec Bohuslav také ledacos šikovného svedl, snad jsem se tedy já sám tak úplně neodrodil.

Řečený František Šalanda měl kromě klempířství železářský krámek s domácími potřebami, a stal se tak svým způsobem šiřitelem inovací na venkově, zejména jako distributor velocipédů, jak se tehdy říkalo jízdním kolům. Dochovala se dokonce jeho (bohužel nekvalitní) fotografie před vlastním krámem; z té doby více rodinných snímků naneštěstí není k dispozici. Uvedený fotografický dokument byl zařazen do stati, která v tomto čísle Historické sociologie naznačuje problematiku studia (auto)mobility ve venkovském mikroregionu na Poličsku. Vysvětleme ještě, že lidé na vesnici se tenkrát tak často nefotografovali, nebot' snímky byly dosti drahé.

Zůstávám skromný a konstatuji, že v tomto čísle se lze začíst do důležitějších textů, které se týkají různých oblastí. Za zvýšenou pozornost stojí hned první článek Christopha Reinprechta, Nory Walchové a Jiř́iho Šubrta o méně známé kapitole rakouské sociologie, v níž se uplatňuje slibná perspektiva topografie vědy. Operuje se zde s pojmy vědecké pole, místo, lokalizace, figurace a v neposlední řadě tu nalezneme dnes všudypřítomnou sít. Dále $\mathrm{k}$ problematice paměti se nápaditě vyjadřuje Tomáš Karger ve svém př́spěvku o situační analýze mnemonických praxí mládeže. Takřka kmenový autor Petr Kokaisl ve svém pojednání poukázal na etnické procesy v Kyrgystánu, v němž Ujguři tvoří „dvě odlišné části jednoho národa“. Jinak Karel Černý pojednal ve své studii o iráckých jezídech a připravil do tisku přednášku Tobiho Huffa o Maxovi Weberovi, islámu a racionalizaci.

Do Historické sociologie se snažíme zařazovat různé časopisecké žánry, a to nejenom recenze a glosy, nýbrž i diskuzní fórum. Žánr „Kulatého stolu“ pod vedením Ludi Klusákové tentokrát reprezenzuje 16 autorů debatujících o adaptačních procesech a jejich aktérech 
v modernizující se Evropě. Konečně za redakční úspěch považujeme také skutečnost, že se nám podařilo získat Juraje Šucha pro glosování díla nedávno zesnulého historika Haydena Whitea.

Jedna z věcí, které zaslouží, aby byly v tomto kontextu připomenuty, je samotný vznik našeho časopisu, který začal vycházet před deseti lety (tehdy ještě v Nezávislém centru pro studium politiky v Kolíně). Jeho počátky byly organicky spojeny s dalším významným aktem, jímž bylo v roce 2009 otevření magisterského studijního programu Historické sociologie na Fakultě humanitních studií Univerzity Karlovy. K charakteristickým rysům pracoviště, jež tento program na FHS UK rozvíjí, patří výrazné úsilí o posilování mezinárodní spolupráce, což je mimo jiné patrné i na struktuře přispěvatelů našeho časopisu. Jedním z dokladů toho, že se tato mezinárodní spolupráce daří, je např́klad studie našeho ruského kolegy, prof. Nikolaje P. Narbuta, která oněch deset let rozvoje oboru v pedagogické a badatelské oblasti bilancuje [Narbut 2019].

V našem kaleidoskopu nesmí chybět malý posthumní medailon, který se týká Erica Olina Wrighta (1947-2019), jenž dlouhodobě působil jako sociolog na University of Wisconsin (USA) i jako ředitel Haven's Center for the Study of Social Structure and Social Change. Stručně řečeno reprezentoval analytický marxismus, vyjadřoval se k sociální stratifikaci, přičemž akcentoval zkoumání sociálních nerovností, jež se vyskytují ve všech typech společností. Mimoto moderně aplikoval teorii her na analýzu kapitalistického a dělnického jednání. Dále v rámci tř́íní analýzy v kontextu sociologické metodiky zdůrazňoval tři zásadní tradice: Marxovy vztahy produkce, Weberovy tržní kapacity a Durkheimovo zaměstnání (dělbu práce). Wright byl na Západě obecně akceptován jako významný teoretik tříd; věnoval ovšem pozornost i střední třídě. Podílel se rovněž na rozsáhlém komparativním projektu o třídní struktuře, biografii a vědomí ve vyspělých průmyslových společnostech.

Na Wrighta v jedné ze svých nejdůležitějších knih odkazuje i významný britský socio$\log$ Anthony Giddens. Lapidárně jeho myšlenky shrnul takto: „Podle Wrighta existují v moderní kapitalistické výrobě tři dimenze kontroly nad ekonomickými prostředky, podle nichž lze rozlišit hlavní politické třídy. Těmito třemi dimenzemi jsou 1. investice nebo finanční kapitál, 2. fyzické výrobní prostředky (půda, továrny kanceláře) a 3. pracovní síly“ [Giddens 2005: 261].

Hodí se dodat, že Eric Olin Wright pronesl 23. května 2005 na Univerzitě Karlově přednášku pro široké auditorium Modré posluchárny v Celetné ulici. Na jeho vystoupení zvala Katedra sociologie FF UK; tematicky se přednáška věnovala problematice The Continuing Relevance of Class (Kontinuity významu třídy). V rámci Wrightova výkladu zaznívaly myšlenky o sociální nerovnosti jakožto centrálním horizontu - právě tř́idy podle něho zůstávají důležitým konceptem pro analýzu nerovnosti v současných kapitalistických společnostech. Následně pak vysvětloval cesty, na jejichž základě je koncept třídního vykořistování důležitý pro chápání chudoby v bohatých společnostech.

Pozoruhodné bylo, jak otevřeně náš tehdejší host později hovořil o své nevyléčitelné chorobě, která vyžadovala chemoterapii a následnou transplantaci kostní dřeně. Statečně nesl fyzické útrapy a do posledních chvil psal svou poslední knihu nazvanou How to Be an Anticapitalist for the 21st Century (Jak být antikapitalistou pro 21. století). Zatím je pro vydání k dispozici její první část. Každopádně skon Erica Olina Wrighta 23. ledna tohoto roku je velkou ztrátou pro světovou sociologii. 
Třebaže v předchozích řádcích jsem občas dával průchod vlastnímu neodbytnému skepticismu, nic se nemění na tom, že samotná doména historické sociologie (disciplíny i časopisu) se nachází ve stabilizovaném a slibném nastavení. Především díky tomu, že domácí centrální akreditační komise schválila dobu trvání výuky oboru historická sociologie na deset let. Navíc si troufnu prohlásit, že oborové periodikum disponuje stále silnějším rezervoárem kvalitních příspěvků. Nevím, zda se naplní vysoké ambice patrné během pozvolné př́pravy ,japonského“ čísla našeho žurnálu pod taktovkou Johanna Palla Arnasona. Nakonec se ale přikláním k optimistickému pohledu do budoucnosti, at už jej v redakci budeme čerpat $\mathrm{z}$ nových možností vylepšovat profil našeho časopisu, nebo z přízně svých věrných čtenářů.

Bohuslav Šalanda

\section{Literatura}

Bendová, Helena - Strnad, Matěj (ed.) [2014]. Společenské vědy a audiovize. Praha: AMU.

Bendová, Helena [2016]. Umění počitačových her. Praha: NAMU.

Didi-Huberman, Georges [2006]. Před časom. Dejiny umenia a anachronismus obrazov. Bratislava: Kalligram.

Fišerová, Michaela [2015]. Obraz a moc. Rozhovory s francouzskými mysliteli. Praha: Karolinum.

Fišerová, Sylva (ed.) [2012]. Homér: Odysseia. Praha: Academia.

Fischerová, Sylva - Starý, Jiří (ed.) [2016]. Starodávné bejlí. Obrysy populární a brakové literatury ve starověku a středověku. Praha: Univerzita Karlova, Filozofická fakulta.

Giddens, Anthony [2005]. Sociologie. Praha: Argo.

Jakubec, Ivan [2018]. Společenská dimenze automobilismu. Historická sociologie (2): 127-133.

Jakubec, Ivan - Šternberk, Jan [2018]. Cestovní ruch pod dohledem třetí říše. Praha: Karolinum.

Janeček, Petr [2017]. Mýtus o Pérákovi. Městská legenda mezi folklorem a populární kulturou. Praha: Argo.

Luffer, Jan [2014]. Katalog českých démonologických pověstí. Praha: Academia.

Narbut, Nikolay P. [2019]. Ten years of historical sociology in Prague: A new perspective branch of Czech sociology. RUDN Journal of Sociology 2019 (1): 167-174.

Otčenášek, Jaroslav [2012]. Antropologie narativity. Problematika české pohádky. Praha: Etnologický ústav AV ČR.

Otčenášek, Jaroslav (ed.) [2019]. České lidové pohádky I - Zvírecí pohádky a bajky. Praha: Vyšehrad.

Pohunek, Jan [2015]. Stíny mezi stromy. Extravilán v současných pověstech. Praha: Národní muzeum. 